\title{
Reflections on Hemingway's Life Experience in A Farewell to Arms (Historical-Biographical Study)
}

\author{
Everhard Markiano Solissa \\ Faculty of Teacher Training and Education, Universitas Pattimura, Ambon, Indonesia \\ eversolissa@yahoo.com
}

\begin{abstract}
The purpose of this research is to find and describe the relationship between Hemingway's life story in A Farewell to Arms and his real life. This research is a qualitative descriptive study with a historical-biographical approach, that is, an approach that sees literature as the life and era of its author. The research data is in the form of novel texts that describe the characters and the setting of the place. The data were obtained by using the readingnote technique, namely reading the data carefully and recording the parts of the data related to the setting, characters, and characterizations. The data were analyzed by describing the setting and characters in A Farewell to Arms then compared with the data on The German Wars 1914-194, World War I and http://id.wikipedia.org/wiki/Ernest_Hemingway. The results of the analysis show that there is a relationship between the character and place in A Farewell to Arms and the author's life.
\end{abstract}

\section{Keywords}

historical-biography, author, novel; figures, setting

\section{Introduction}

Literature is the inspiration for life that is manifested in the form of beauty. At first, the author sees the world, life, and events, and then it is crafted into literary works (Aminuddin, 1980, p. 1). Efforts to create literary works that are built and colored with high imagination will give birth to meaningful literary works. According to Wellek and Warren (1995, pp.78-80), the production of a literary work is influenced by three factors, i.e., the author's life experience and psychology, the social condition of society, and philosophy - things related to thoughts and views of life. Of the three factors, the first factor plays the most important role. The reason is that the author as an individual has thoughts and values that he adheres to. Thus, the factors of thought, philosophy, and theology are inherent in the author. According to Wellek and Warren (1995, pp. 86-88), even though literary works are not photocopying of life, there are similarities and parallels between literary works and their authors.

According to Nurgiantoro (2000, p.71), a novel can be seen as the result of dialogue, an expression of various life problems after going through an intense, selective subjective appreciation, and being processed with imaginative-creative power by the author into an imaginary world. A novel is a literary work created from the author's imagination. It is the picture of life because the plot contained in the novel was born through the life experience of either the author himself or others that serves as the idea (Putriyanti et al, 2019).

Hemingway, one of the world's greatest authors, brought many of his personal experiences into literary works. The Snows of Kilimanjaro and The Short Happy Life of Francis Macomber are fictional outgrowths of his experiences in Africa. His experience of the civil war in Spain is recorded in For Whom the Bell Tolls. His admiration for the town of Acciaroli, known as a fishing village, was the idea for The Old Man and the Sea. This novel was quoted when Hemingway was awarded the Nobel Prize in Literature in 1954. 
A Farewell to Arms is a Hemingway's novel published in 1929, depicting the love story between an American ambulance driver Frederic Henry and an English nurse Catherine Barkley. The plot is directly inspired by his experiences with Sister von Kurowsky di Milano; the intense pain of giving birth to his son Patrick by his second wife Pauline inspires the process of giving birth to Catherine in the novel. This novel with the background of World War I depicts the Italian-Austrian war. This war took place along the Isonzo River in Eastern Italy, which is now part of Slovenia. In this war, Italy was part of America's ally while Austria was allied with Germany. This war ended in the defeat of Italy and killed hundreds of thousands of soldiers, mostly from the Italian side.

A Farewell to Arms was translated into Indonesian by Toto Sudarto Bachtiar as Pertempuran Penghabisan and was published for the first time by Yayasan Pustaka Obor Indonesia in 1997. This novel not only reflects the state of the soul of the author himself but also the state of the soul of the entire generation at that time. The generation who felt the deep misery of World War I was nicknamed the "Lost Generation". This paper focuses on the elements of the characters and places depicted in A Farewell to Arms and the characters and appearances in Hemingway's biography as its author. The aim is to compare these elements to determine their relationship.

\section{Review of Literature}

\subsection{Literature and Biography}

Studying a literary work can be done through intrinsic and extrinsic approaches. An intrinsic approach focuses on the elements that make up the literary works such as theme, plot, setting, point of view, characters, and language style. On the other hand, an extrinsic approach is used to analyze literary works concerning outside fields such as biography, psychology, philosophy, and others (Wellek and Warren, 1995, p. 79). The analysis of a literary work involves both approaches because understanding the outside and the elements in a literary work must begin with an understanding of the intrinsic element.

Related to the character's personality, a biography needs to pay attention to family background, education, socio-cultural environment, and self-development (Kuntowijoyo, 2003, p. 207). This means a biography is always related to what a character experiences, sees, and feels. Therefore, the biography is a reflection of the character himself. Wellek and Warren (1995, p. 82) say that the relationship between literary works and authors can be seen from three points of view. First, biography can explain the actual process of creating literary works. Second, the focus of attention starts from the literary works to the author's personality. Third, biography can be needed as material for science. The first point of view treats biography as a means of explaining the process of creating literary works because it can provide information about the author's childhood, work experiences, family background, friendships, visited places, and so on. In this paper, this point of view is used as a reference.

In discussing literary works and biography, Wellek and Warren (1995, pp. 82-88) explain that the relationship between literary works and authors cannot be explained simply. The author does not have to have the same ideas, feelings, and views as the characters in the story because a literary work is not a biographical document. However, literary works can be considered as "fragments of deep confession". The authors write down what they experienced and felt in their work, which can be proven by their confession in diaries, personal letters, or other biographical data. It is further explained that, however, there are still indirect relationships, parallels, and similarities between literary works and their authors. An author's work can be a mask or a dramatized 
convention. But the convention is based on the author's own life experience (Wellek and Warren, 1995, p. 88).

From those statements, it can be concluded that the relationship between ideas, views, feelings of characters, and places of events in literary works and the author can be interpreted with two possibilities. First, there are literary works that reflect the life of the author himself. What is written is a reflection of his own experience, which has been mixed with high imagination. The result is a literary work that is not quite the same as the story of his life's journey. Nurgiantoro called this process "creative-imaginative". Second, what is told in a literary work is only the author's "dream" or imagination. To choose or determine one of these possibilities, a biography is needed as a verification tool because a biography is a true story about someone's life.

\subsection{Setting}

Setting refers to the environment that surrounds an event in the story (Stanton, 2007, p. 35). Abrams (in Nurgiantoro, 2005, p. 216) said that the setting, which is also called the fulcrum, suggests the notion of place, time relationship, and the social environment in which the events occur. According to Nurgiantoro (2005, p. 217), the function of the setting is to provide a concrete and clear basis for the story. It is important to give the reader a realistic impression, creating a certain atmosphere as if it exists and is happening. Therefore, one of the functions of the setting is as a metaphor and expression of the characters (Wellek and Warren, 1995, pp. 290-291). If the author describes the place, where the story character lives, which is dirty, dusty, and his house poles are eaten by termites, which means the author is describing the character himself.

\subsection{Character}

According to Stanton (2007, p. 33), a character refers to two things, namely the individuals who appear in the story, and the nature and attitude of these individuals. Abrams, whose opinion is followed by Nurgiantoro (2005, p. 165), mentions the character of the story as a person(s) who is shown in a narrative work, or drama, which readers interpret as having moral qualities and certain tendencies expressed in speech and action. Meanwhile, Jones said that characterization is a clear depiction of a person who is portrayed in a story (Nurgiantoro, 2005, p. 165). Kenney (in Nurgiantoro, 2005, p. 166) explains that characterization refers to the way the author depicts the characters in a fictional story. Usually, a story character develops a certain personal character according to the author's design. How to express the nature of a character can be done through direct statements, events, conversations, inner monologues, or figures of speech and satire (Nurgiantoro, 2005, p. 37). According to Yara et al, (2019) in a novel told of a variety of conflicting characters and one another, the long story makes the novel one of the literary works that is reckoned with other works. Smiley (2008:14) explains that the novel is a narrative-shaped inscription or description and contains conflicting stories between the one and the other characters. 


\section{Research Methods}

This research is a qualitative descriptive study with a historical/biographical approach, i.e., an approach that sees literary works as the life and era of their authors. According to the historical-biographical critics, it is very necessary to know about the author, the political, economic, and sociological contexts of his time to understand truly the meaning of his literary works. According to Denzin \& Lincolin, a biography is a form of in-depth presentation of a person's life story accompanied by vivid illustrations so that readers can take positive values from the story. Data about the author, Hemingway, is taken from http://id.wikipedia.org/wiki/Ernest_Hemingway. Considering this novel is set in World War I, the author also accesses The German Wars 1914-194, and World War I, which presents a lot of news about the war, especially the Italian-Austrian war. The research data were obtained by reading-note technique, namely reading the data carefully then recording parts of the data related to the background and characters and characterizations. The data of this study were analyzed by describing the setting and characters in A Farewell to Arms then comparing them with the data at The German Wars 1914-194, World War I, and http://id.wikipedia.org/wiki/Ernest_Hemingway and. The results of the comparison are then concluded whether there is a relationship between the two or not.

\section{Results and Discussion}

\subsection{Place Relationship}

The events in this novel are set in several places such as Plava, the San Gabriele Mountains, the Carso Mountains, Monfalcone, Carpathia, the Tagliamento River, and others. In these places, there was fighting between Italian and Austrian forces. This can be seen in the following quote.

"We cannot win wars through victories. What good would it do if we took San Gabriele? Or the Carso Mountains, Monfalcone or Trieste? Where will we be with it all? Did you see the distant mountains? Do you think we will succeed in capturing all those mountains? That would only be possible if the Austrians stopped fighting. . ." (Hemingway, 2002, p. 66).

At that time, Lieutenant Henry, who was serving in Italy as a medical officer, at all times had to carry wounded soldiers from the battlefield to healing posts before being taken to the hospital. Thus, if every gun battle occurs in any location, in the forest, in the mountains, in the river, he must go there because every time there is gun contact there must be soldiers who are injured and even died. In World War I, Wilmott said that the war between Italy and Austria occurred along the Isonzo River in Eastern Italy, which is now part of Slovenia. The Isonzo War was part of World War I. In this war, Italy allied itself with America while Austria is allied with Germany (2003, p. 15).

The strategy employed in this battle was known as the "Trench War" because the soldiers took refuge in dirty, muddy trenches while opening fire on the enemy. This stretch is used by Italian and Austrian troops.

The Austrian trenches above a hillside were only a few yards from the Italian battle line...

I went down the narrow road to the river at the foot of the hill, left my car at the healing post at the foot of the hill, crossed the pontoon bridge protected by the shoulder of the mountain, and then through the ditches, I went into the ruined town 
and came to the edge of the slope. They all live in foxholes ... It was quiet, hot, and dirty (Hemingway, 2002, p. 30).

It was also explained by Goodspeed that Trench War was the main strategy of World War I. Over the next several years, it could be said that soldiers lived in these trenches. Life there is hard. The soldiers live under a constant bomb threat. The bodies of those who had died had to be left in these places, and the soldiers had to sleep beside the bodies. When it rains, the trenches get flooded with mud (Goodspeed, 1985, p. 199). In A Farewell to Arms, it is told that in a battle, Lieutenant Henry and a mortar trench hit his four friends who were in a foxhole so that they were injured and even one of his friends, Passini, died. Lieutenant Henry's injuries were so bad that he had to be taken to Milan to be treated there.

By paying attention to the setting in A Farewell to Arms and the setting in Hemingway's biography, it can be concluded that there is a relationship between the two. Hemingway brings back the scene of the ambulance driver into his novel. In Hemingway's biography, these places are not alien to him. In his biography accessed from http://id.wikipedia.org/wiki/Ernest_Hemingway, it is explained that Hemingway left his job as a reporter and joined the United States Army to witness the action in World War I. He failed a medical due to his poor eyesight. Because of that, he joined the Red Cross Ambulance Corps and left for Italy. On the Italian front on 8 July 1918, he was wounded while delivering supplies to the army and his career as an ambulance driver ended. Shrapnel from Austrian trench mortar, which left pieces in his legs, hit him. After that, he was admitted to a hospital in Milano run by the American Red Cross.

\subsection{Character Relationships}

The characters that will be discussed in this paper are the characters of Henry and his lover Catherine. In A Farewell to Arms is told that in a battle, a mortar trench hit Henry and some of his friends so that Henry had to be taken to Milan to be treated. It is also told that while serving on the Italian front he had a love affair with Catherine, an English nurse who also served there. Even though he is hit by shrapnel that injured his body, his character tries to help his injured friend. For his services, he will be awarded a bronze medal.

"You get a token of service. They wanted you to get the medagli d'argento, but they only managed to get the bronze medal."

"What for?"

"Because you were badly injured..."

"Haven't you carried someone on your back? Gordini says you have carried some on your back ..." (Hemingway, 2002, pp. 83-85)

Furthermore, it is also told that in a conversation with his friends, Henry asked their opinion about the ongoing war. His friends who were average mechanics expressed that they did not like this war and hoped that it would end soon. They want to be free from this miserable and deadly battle.

"There is nothing worse than war in this world," said Manera excitedly.

"I don't think so," Passini said, still. "What does one defeat mean in the end? Very simple, we're going home.” (Hemingway, 2002, p. 65).

Henry's character in this novel is also told that he likes to drink liquor such as strega, grappa, chianti, cognac, vermouth, marsala, and capri. Even in his illness, he still consumes these drinks. That is what caused him to have jaundice. 
... and after that I reached under the bed for a bottle of cinzano, put the bottle of tegk luru on my stomach, while the cold glass rested on my stomach, and I took a small sip ... (Hemingway, 2002, p. 115).

"And all this time I feel sorry for your jaundice. It seems that pity is in vain." (Hemingway, 2002, p. 184).

Hemingway's biography tells us that on his way to the Italian front, he stopped in Paris, which was under constant bombardment by German artillery. Instead of staying in relative safety at the Florida Hotel, he tried to get as close to the battlefield as possible. He has also received awards in the form of the Silver Medal for military bravery (Medagli d'argento) in World War I, the Bronze Star (War Correspondent - Military Extraordinary in World War II) in 1947, the 1953 Pulitzer Prize for The Old Man and The Sea, as well as the 1954 Nobel Prize for Literature. Rampan (2005: 172) states that in addition to being a fighter, having boxed, and likes deep-sea fishing, Hemingway was also known as a heavy drunkard. It is also recounted in his biography that throughout his life, Hemingway was a heavy drinker and so he became addicted to alcohol in his old age.

From this explanation, two things can be concluded. First, Lieutenant Henry in this novel is a picture of Hemingway himself. Henry, who works in the health department as an ambulance driver, the events experienced during the Italian war until he was brought to Milan, the honors he received, and the habit of consuming alcohol are all reflections of Hemingway in the real world. Second, the antiwar attitude expressed by the character Henry and some of his friends in the novel can be seen as a projection of Hemingway's principle. According to Rampan (2005, p.170), Hemingway's works show the symptom of "The Lost Generation" because the era he is living in shows a reality without hope, despair, fear, and horror because of war. He is a witness to the terrible pain, suffering, hunger, death, and destruction of humanity.

This is in line with what Fauziyah and Eva Syarifah Wardah said that post-war literary works describe mental illness. These works reflect not only the mental state of the artist but also the mental state of the entire generation, namely "The Lost Generation" (2020, p. 150). The second character to talk about is Miss Catherine Barkley. In this novel, it is told that Lieutenant Henry fell in love and had a relationship with Catherine until the end. She was pregnant and had to undergo a caesarean section at the time of delivery in the hospital. When they first met, Henry and Catherine had fallen in love.

Not long after, we said good night and left. On the way back, Rindaldi said, "Miss Barkley seems to like you more than me. It is very clear ..." (Hemingway, 2002, p. 27).

Since that first meeting, almost every day Henry was never absent from visiting Miss Barkley in her villa unless he had to go to the healing posts when there was gunfire between Italian and Austrian troops.

The next day, I visited Miss Barkley again. She was not in the garden and I went to the side door of the villa, where ambulances used to pass ..." (Hemingway, 2002, p. 28).

Returning from the healing posts, Henry went to Miss Barkley's place. This time, Henry did not address her as Miss Barkley but as Catherine. This shows that there is no significant distance between them because they like each other.

"And you call me Catherine?"

"Catherine". We continued walking for a while and then stopped under a tree. 
"Say it! I have returned to Catherine in the evening!"

"Oh, my love, you are back now." (Hemingway, 2002, p. 39).

When Henry was hit by a mortar trench explosion and had to be taken to Milan for treatment, it turned out that he met Catherine who was also transferred there. This is where their love relationship blossomed again and finally, Catherine became pregnant.

... What we have done is simply too crazy. We can't do it again."

"At night, of course, you can."

But we have to be very careful (Hemingway, 2022, p. 121)

"And now that you are ready, what shall I do?"

"Come back to bed"

"Good. I will come soon."

"O, my love, my love, dear."

"You see," he said, "I will do whatever you want."

"My love, dear." (Hemingway, 2002, p. 137).

The question is who Hemingway's model was when he created the character Catherine in this novel. Let us look again at Hemingway's biography. His biography tells us that when a mortar explosion on the Italian front hit him, he was taken to Milan for treatment. There, not much he could do for entertainment. He often drank and read newspapers to pass the time. It was the place where he met Sister Agnes von Kurowsky of Washington, D.C., one of 18 nurses who treated four patients each. Hemingway fell in love with Sister Agnes, who was six years older than he was, but their relationship did not continue. After she returned to the US, Sister Agnes fell in love and married another man.

Thus, it can be concluded that Sister Agnes von Kurowsky was the model Hemingway chose to become the character of Catherine in this novel. However, there is a slight difference between the love story of Hemingway and Sister Agnes von Kurowsky and the love story of Lieutenant Henry and Catherine. In his biography, Hemingway has a love affair with Sister Agnes von Kurowsky after he was taken to the hospital in Milan whereas in A Farewell to Arms Lieutenant Henry and Catherine have been in that relationship long before Henry transferred to Milan.

Hemingway's biography also tells us that in 1928, his son, Patrick, was born in Kansas City. The child was born by cesarean after his mother, Pauline, gave birth to him painstakingly. The details of this incident by Hemingway are included in the concluding part of the novel.

"What is your advice?"

"There are two possibilities. The first possibility, a birth with pliers, which may tear the uterus and is very dangerous. Besides, it may also have bad consequences for the baby, and another possibility is birth by cesarean."

"What is the danger of a cesarean section? What if she dies?"

"The danger is no greater than in ordinary childbirth."

"How good in your opinion."

"I recommend a cesarean. If she were my wife, my recommendation would be the same."

“Then you must operate as soon as possible." (Hemingway, 2002, pp. 408-409). 
The surgery run well, but eventually, Catherine and her newborn baby died. The baby died because the cord was wrapped around his neck. Meanwhile, Catherine died from bleeding profusely. This part is different from the story in Hemingway's biography. In his biography, his wife Pauline and son Patrick live on. This part gives the reader a deep sad impression because after following their (Henry and Catherine) journey, which is, so tiring and always overshadowed by fear, this story must end with the death of one of the characters. The author does this deliberately to show his attitude towards war itself. War only brings suffering and death, "war is crazy", even a child who has not had the chance to see the world must suffer the consequences.

\section{Conclusion}

From the description in the discussion section, it can be concluded that there is a close relationship between A Farewell to Arms and the personal life of its author. This can be seen from the characters, the places, and times of events in the novel with Hemingway's real life. In terms of character, Hemingway creates fictional characters as a reflection of himself and the people who have been close to him. Henry, as the main character in this novel with his work, experiences, attitudes, and his love story with Catherine is a reflection of his personality. Meanwhile, the character Catherine is a reflection of Hemingway's experience with Sister Agnes von Kurowsky, who had cared for him in Milan when he was hit by a mortar explosion. What Catherine experiences while giving birth in the hospital is a reflection of the pain that Hemingway's second wife, Pauline, experienced when she gave birth to their second child.

In terms of location, this novel can also be said to describe every place that Hemingway has traveled or visited while on duty on the Italian front. They correspond to the site of the fighting between Italian and Austrian soldiers during World War I, as well as to his treatment place in Milan.

\section{References}

Aminuddin, (1980). Pengantar Apresiasi Karya Sastra. Bandung: Sinar Baru Algensindo.

Denzin, Norman K, \& Lincolin Yvonna S. (2009). Handbook of Qualitative Research. Yogyakarta: Pustaka Pelajar.

Fauziyah, Siti dan Eva Syarifah Wardah (2020). Sejarah Dunia II (Dari Perang Salib sampai Arab Spring). Serang: Media Madani

Goodspeed, Donald James (1985), The German Wars 1914-1945. New York: Random House; Bonanza.

Hemingway, Ernest. (2002). Pertempuran Penghabisan (Diindonesiakan oleh Toto Sudarto Bachtiar). Jakarta: Yayasan Obor Indonesia.

http://id.wikipedia.org/wiki/Ernest_Hemingway (diakses tanggal 01 Maret 2021).

Kuntowijoyo. (2003). Metodologi Sejarah (Edisi Kedua). Yogyakarta: Tiara Wacana.

Nurgiantoro, Burhan. (2005). Teori Pengkajian Fiksi. Yogyakarta: Gadjah Mada University Press.

Putriyanti, O.A., et al. (2019). Religious Education Values in Gita Savitri Devi's Rentang Kisah and Andori Andriani's Doriyaki Novels. Budapest International Research and Critics in Linguistics and Education (BirLE) Journal. P. 560-565.

Rampan, Korrie Layun. (2005). Tokoh-Tokoh Cerita Pendek Dunia. Jakarta: Grasindo. Smiley, J. 2008. 13 Ways Of Looking at The Novel. United States of America: Knopf Double day Publishing Group. 
Stanton, Robert. (2007). Teori Fiksi Robert Stanton (Diindonesiakan oleh Sugihastuti dan Rossi AbiAl Irsyad). Yogyakarta: Pustaka Pelajar.

Wellek, Rene dan Austin Warren. (1995). Teori Kesusastraan (Diindonesiakan oleh Melani Budianta). Jakarta: Gramedia Pustaka Utama.

Willmott, H.P. (2003). World War I. New York: Dorling Kindersley.

Yara, N.Y., et al. (2019). Transformation Poem Nyanyian Angsa by W. S. Rendra to Novel Maria Zaitun by Joko Santoso: Intertextual Study. Budapest International Research and Critics Institute-Journal (BIRCI-Journal). P. 327-333 